ISSN: 2224-0616

Int. J . Agril. Res. Innov. \& Tech. 2 (2): 1-8, December, 2012 Available online at http://www.ijarit.webs.com

\title{
MARKER-ASSISTED BACKCROSSING FOR IDENTIFICATION OF SALT TOLERANT RICE LINES
}

\author{
M. Moniruzzaman', M.S. Alam ${ }^{2 *}$, J.A. Rashid ${ }^{3}$, S.N. Begum ${ }^{4}$ and M.M. Islam ${ }^{5}$
}

Received 30 July 2012, Revised 18 November 2012, Accepted 25 December 2012, Published online 31 December 2012

\begin{abstract}
SSR or microsatellite markers are proved to be ideal for making genetic maps, assisting selection and studying genetic diversity in germplasm. SSR markers are playing important role to identify gene for salt tolerance that can be helpful for plant breeders to develop new cultivars. The experiment was conducted during the period from July 2009 to November 2010 in the experimental field and Biotechnology Laboratory of Plant Breeding Division, Bangladesh Institute of Nuclear Agriculture (BINA), Mymensingh to identify salt tolerant rice line of $\mathrm{BC}_{1} \mathrm{~F}_{1}$ progenies of Binadhan- 5 x FL- 478 using SSR markers. Salt tolerant genotype, FL-478 was crossed with high yielding variety, Binadhan- 5 . Randomly selected 40 $\mathrm{BC}_{1} \mathrm{~F}_{1}$ progenies along with their two parents (Binadhan-5, FL-478 and F1) were genotyped with microsatellite or SSR markers for identification of salt tolerant rice lines. Parental polymorphism survey was assayed by 10 SSR markers and three polymorphic SSR markers viz., RM 336, RM 510, and RM 585 were selected to evaluate $B_{1} F_{1}$ rice lines for salt tolerance. In respect of Primer RM 336, 11 lines were found as salt tolerant and 25 lines were heterozygous and 3 lines were susceptible. Primer RM 510 identified two tolerant, 14 heterozygous and 22 susceptible lines. And primer RM 585 identified 4 lines as tolerant and 35 lines as susceptible. Thus, these markers could be efficiently used in tagging salt tolerant genes, in marker-assisted selection and quantitative trait loci (QTL) mapping. The selected $\mathrm{BC}_{1} \mathrm{~F}_{1}$ could be used for developing $\mathrm{BC}_{2} \mathrm{~F}_{1}$ and $\mathrm{BC}_{2} \mathrm{~F}_{2}$ and mapping genes for salinity tolerance.
\end{abstract}

Keywords: Salinity, Marker-assisted backcrossing (MABC), and SSR marker

${ }^{1}$ Biotechnologist (Field Research), Bangladesh Jute Research Institute, Manikgonj, Dhaka, Bangladesh

${ }^{2}$ Scientific Officer (Plant Breeding), Regional Agricultural Research Station, BARI, Akbarpur, Moulvibazar

${ }^{3}$ Executive, R\&D (Biotechnology/ Agriculture/ Microbiology/ Enzyme), MATEX Bangladesh Ltd. Dhaka

${ }^{4}$ Senior Scientific Officer, Plant Breeding Division, Bangladesh Institute of Nuclear Agriculture, Mymensingh.

${ }^{5}$ Principal Scientific Officer \& Head, Biotechnology Division, Bangladesh Institute of Nuclear Agriculture, BAU campus, Mymensingh, Bangladesh

*Corresponding author's email: asarowar04bau@gmail.com (M.S. Alam)

\section{Introduction}

Rice (Oryza sativa L.) is the most important food crop of the world. Eighty five per cent of it is devoted for human consumption (IRRI, 1997). The Green Revolution of the 1970s resulted in remarkable increases in rice production. Since then, the rate of production in most rice-growing countries has slowed down and has now reached a plateau (Maclean et al., 2002).

Salt stress is a major problem in coastal areas because of seawater intrusion during high tide and the rising shallow saline groundwater, particularly during the dry season. Saline soil covers our earth's surface, estimated to be from 400 to 950 million ha (Lin et al., 1998). More than 54 million ha of rice land in Asia are now affected by salinity. About 9.5 million ha of saline soils can be managed by large-scale irrigation and drainage schemes and by chemical treatment of soil, but the scale of the problem renders these solutions too costly (Gregorio et al., 2002). Salinity is one of the major obstacles in increasing production in rice growing areas worldwide, which is an ever-present threat to crop yield. Accumulation of salt in the soil has deleterious effects and leads to a reduction in crop production, including rice. Use of salttolerant variety considered the most economical and most effective way of increasing crop production on saline soils. Therefore, development of salt tolerant varieties considered as one of the strategies to increase rice production in saline prone coastal areas.

Microsatellite markers based on SSRs have been developed in many crop species, including rice, tomato, soybean and others. These markers detect simple sequence length polymorphism 
(SSLP) and are rapidly replacing RFLPs or others for genetic studies, due to their technical simplicity, the small amount of starting DNA required, the relatively low cost for the user, the level of allelic diversity and high power of resolution (Panaud et al., 1995; McCouch et al., 1997). Secondly, PCR based assay makes them easily detectable in gel electrophoresis. SSR or microsatellite markers are proved to be ideal for making genetic maps (Islam, 2004; Niones, 2004), assisting selection and studying genetic diversity in germplasm. Microsatellite marker analysis is promising to identify major gene locus for salt tolerance that can be helpful for plant breeders to develop new cultivars. The objective of this study was to identify salt tolerant rice line of $\mathrm{BC}_{1} \mathrm{~F}_{1}$ progenies of Binadhan- 5 x FL-478 using SSR markers.

\section{Materials and Methods}

\section{Location and time}

For the marker assisted backcrossing (MAB) the experiment was conducted during the period from July 2009 to November 2010 in the experimental field and Biotechnology Laboratory of Plant Breeding Division, Bangladesh Institute of Nuclear Agriculture (BINA), Mymensingh.

\section{Plant materials}

Forty $\mathrm{BC}_{1} \mathrm{~F}_{1}$ progenies were selected for this study from the backcross made between rice of $F_{1}$ (Binadhan-5 $x$ FL-478) and Binadhan-5. Binadhan- 5 is a salt susceptible but one of the popular HYV of irrigated rice ecosystem in Bangladesh. On the other hand, FL-478 is one of the salt tolerant lines of IRRI. Binadhan- 5 was the recurrent parent and FL-478 was the nonrecurrent donor line. $F_{1}$ seeds were collected and grown for developing $\mathrm{BC}_{1} \mathrm{~F}_{1}$ seedlings during Aman season 2010. $F_{1}$ plants were crossed with Binadhan-5 following of backcrossing and 133 $\mathrm{BC}_{1} \mathrm{~F}_{1}$ seeds were developed (Fig. 1). Among these, 40 seedlings were selected to collect the leaf to make foreground selection genotypically at the molecular level (by using SSR markers).

\section{Development of F1 population (Binadhan- $5 \times$ FL 478) of rice}

On the basis of research works based on phenotypic evaluation conducted by Islam et al. (2007), Siddika et al. (2007), one rice genotype (FL-478) was selected as parent for transferring salt tolerant genes to high yielding rice genotype (Binadhan-5). Crossing programe was conducted during Boro season in 2009, where Binadhan-5 was the recurrent parent and FL-478 was the nonrecurrent donor line. Binadhan-5 and FL-478 were selected for development of F1 based on phenotypic performance of fifteen rice germplasm at reproductive stage.
$\mathrm{F}_{1}$ seeds were collected and grown for $\mathrm{BC}_{1} \mathrm{~F}_{1}$ seedlings during Aman season in 2010. Eight seeds of selected $F_{1}$ lines were grown in the pot. Then $F_{1}$ plants were crossed with Binadhan- 5 following of backcrossing and $133 \mathrm{BC}_{1} \mathrm{~F}_{1}$ seeds were developed. Among these, 40 seedlings were selected to collect the leaf to make foreground selection genotypically .

\section{Field experiment}

For easy handling and carrying, the experiment was conducted on the plastic pot (10L bucket). All kinds of recommended doses of fertilizers were applied properly. Cultural practices were followed as and when necessary. The pots were labeled with pot labeler.

\section{Production of $\mathrm{BC}_{1} \mathrm{~F}_{1}$ plants:}

Three sets of recurrent parental line (Binadhan5) and one set of $F_{1}$ (Binadhan-5/ FL-478) were seeded at an interval of 10 days starting from 11 June 2010. All the intercultural operations, diseases and pest management were done properly. Backcrossing was done with Binadhan5 by applying synchronization of flowerings. 133 $F_{1}$ seeds were developed through successful backcrossing. Seeds were dried into seed dryer at $65^{\circ} \mathrm{C}$ for seven days. Then the well-dried seeds were soaked by clear water at 24 hours into a Petri dish by covering a tissue paper. After that, water was removed and kept for sprouting within two days. Then the well-sprouted $\mathrm{BC}_{1} \mathrm{~F}_{1}$ seeds were placed into seed box for the development of $\mathrm{BC}_{1} \mathrm{~F}_{1}$ seedling. After 24 to $26 \mathrm{DAS}$, seedlings were transplanted into the previously prepared pots in the field. 85 seedlings were successfully survived for the next backcrossing activities.

\section{Collection of leaf sample (Binadhan-5, FL-478, $\mathrm{BC}_{1} \mathrm{~F}_{1}$ Lines) for DNA extraction}

The seedlings of two Parents (Binadhan-5, FL478), $\mathrm{F}_{1}$ and $\mathrm{BC}_{1} \mathrm{~F}_{1}$ population rice germplasm were raised in pots at the glasshouse of BINA at the different growing season. Young vigorously growing fresh leaf samples from these seedlings were collected from 21-day-old seedlings to extract genomic DNA. Initially, healthy portion of the youngest leaves of the tiller were cut 3" apart with sterilized scissors and washed in distilled water and ethanol (70\%), and dried on fresh tissue paper to remove spore of microorganisms and any other source of foreign DNA. The collected leaf samples were then kept in polythene bags for avoiding any damage of the leaf tissues. The bags were placed in an icebox to carry it in Laboratory and finally, the samples were stored in $-80^{\circ} \mathrm{C}$ freezer with marking. 


\section{Genomic DNA extraction}

Extraction of DNA was done using the mini preparation Cetyl Trimethyl Ammonium Bromide (CTAB) method from 3" young leaves tissues of 21-day old seedlings. Ten random primers viz. RM21, RM80, RM152, RM310, RM336, RM510, RM585, RM10720, RM28102, and RM28502 were used for surveying and among them; three primers (RM336, RM510 and RM585) showed polymorphisms during parental survey. These three primers were then utilized for amplification of the DNA sequences of segregating $\mathrm{BC}_{1} \mathrm{~F}_{1}$ lines. The sequence and size of the microsatellite markers (SSRs) are mentioned in Table 1.

Table 1. The sequence and size of the microsatellite markers (SSRs) used for $\mathrm{BC}_{1} \mathrm{~F}_{1}$ survey

\begin{tabular}{|c|c|c|c|c|}
\hline $\begin{array}{l}\text { Primer } \\
\text { Name }\end{array}$ & $\begin{array}{c}\text { Expected } \\
\text { PCR product size (bp) }\end{array}$ & & Primer Sequence & $\begin{array}{l}\text { Annealing } \\
\text { Temp. }\left({ }^{\circ} \mathrm{C}\right)\end{array}$ \\
\hline RM 510 & 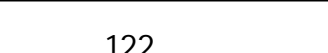 & For. & AACCGGATTAGTTTCTCGCC & 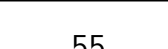 \\
\hline NWJIV & 122 & Rev. & TGAGGACGACGAGCAGATTC & 3 \\
\hline RM 585 & 233 & $\begin{array}{l}\text { For. } \\
\text { Rev. }\end{array}$ & $\begin{array}{l}\text { CAGTCTTGCTCCGTTTGTTG } \\
\text { CTGTGACTGACTTGGTCATAGG }\end{array}$ & 55 \\
\hline RM336 & 154 & $\begin{array}{l}\text { For. } \\
\text { Rev. }\end{array}$ & $\begin{array}{l}\text { CTTACAGAGAAACGGCATCG } \\
\text { GCTGGTTTGTTTCAGGTTCG }\end{array}$ & 55 \\
\hline
\end{tabular}

\section{Amplification of SSR markers}

PCR amplification of simple sequence repeats (SSR) was performed with $1.5 \mu \mathrm{l} 10 \mathrm{X}$ PCR buffer, $0.75 \mu \mathrm{l}$ dNTPs, $1.0 \mu \mathrm{l}$ forward, $1.0 \mu \mathrm{l}$ reverse primers, $0.5 \mu \mathrm{l}$ Taq polymerase, $2.0 \mu \mathrm{l}$ of each template DNA and 8.25 $\mu \mathrm{l} \mathrm{ddH}_{2} \mathrm{O}$ using DNA thermal cycler. The PCR reactions were: initial denaturation at $94^{\circ} \mathrm{C}$ for 5 minutes, then final denaturation at $94^{\circ} \mathrm{C}$ for 1 minute and annealing at $55^{\circ} \mathrm{C}$ for one minute. Polymerization was carried out at $72^{\circ} \mathrm{C}$ for 2 minutes to complete a cycle and cycle was repeated for 34 times. The final extension was at $72^{\circ} \mathrm{C}$ for 7 minutes. After PCR, products were mixed with $3 \mu \mathrm{l}$ of $2 \mathrm{X}$ gel loading dye. Polymorphisms in the PCR products were detected by ethidium bromide staining after electrophoresis on 1.5\% agarose gel using UV transilluminator.

\section{Scoring of bands}

The banding pattern of $\mathrm{BC}_{1} \mathrm{~F}_{1}$ lines was compared with their parents Binadhan-5 (susceptible), FL-
478 (tolerant) and $\mathrm{F}_{1}$. The $\mathrm{BC}_{1} \mathrm{~F}_{1}$ population having similar banding pattern to Binadhan-5 were considered as salt susceptible, similar to FL-378 were considered as salt tolerant and having one allele from Binadhan- 5 and one allele from FL-378 considered as heterozygous. In each marker, allelic bands were designated as $\mathbf{T}$ for tolerant, $\mathbf{S}$ for susceptible and $\mathbf{H}$ for heterozygous.

\section{Results and Discussion}

\section{DNA concentration check}

The extracted DNA was checked through agarose gel to observe the presence of DNA. After electrophoresis, the gel was placed on the UV trans-illuminator in the dark chamber of the large Documentation system. Isolated DNA of selected population showed sickle shape or nearly sickle shape bands that indicated good quality of DNA. 
Table 2. Genotypic performance of parents, $\mathrm{F}_{1}$ and Backcross population $\left(\mathrm{BC}_{1} \mathrm{~F}_{1}\right)$ against 3 SSR markers

\begin{tabular}{|c|c|c|c|c|c|}
\hline \multirow[t]{2}{*}{ *SL No. } & \multicolumn{2}{|r|}{ Sample no. } & \multicolumn{3}{|c|}{ Name of the marker } \\
\hline & & & RM510 & RM585 & RM336 \\
\hline 1 & \multirow{3}{*}{ 郘 } & Binadhan-5 & $\mathrm{S}$ & $\mathrm{S}$ & $\mathrm{S}$ \\
\hline 2 & & FL-478 & $\mathrm{T}$ & $\mathrm{T}$ & $\mathrm{T}$ \\
\hline 3 & & $\begin{array}{l}\text { F1line } \\
\text { (Binadhan-5x } \\
\text { FL-478) }\end{array}$ & $\mathrm{H}$ & $\mathrm{S}$ & $\mathrm{T}$ \\
\hline \multicolumn{6}{|c|}{$\mathrm{BC}_{1} \mathrm{~F}_{1}$ lines } \\
\hline 4 & & $5 / 478-5-3$ & $\mathrm{~S}$ & $\mathrm{~S}$ & $\mathrm{~T}$ \\
\hline 5 & & $5 / 478-5-5$ & $\mathrm{~S}$ & $\mathrm{~S}$ & $\mathrm{H}$ \\
\hline 6 & & $5 / 478-5-6$ & $\mathrm{~T}$ & $\mathrm{~T}$ & $\mathrm{~T}$ \\
\hline 7 & & $5 / 478-5-7$ & $\mathrm{~S}$ & $\mathrm{~S}$ & $\mathrm{H}$ \\
\hline 8 & & $5 / 478-5-8$ & $\mathrm{~S}$ & $\mathrm{~S}$ & $\mathrm{H}$ \\
\hline 9 & & $5 / 478-5-10$ & $\mathrm{~S}$ & $\mathrm{~S}$ & $\mathrm{H}$ \\
\hline 10 & & $5 / 478-5-11$ & $\mathrm{~S}$ & $\mathrm{~T}$ & $\mathrm{~T}$ \\
\hline 11 & & $5 / 478-5-12$ & $\mathrm{H}$ & $\mathrm{S}$ & $\mathrm{T}$ \\
\hline 12 & & $5 / 478-5-17$ & $\mathrm{~S}$ & $\mathrm{~S}$ & $\mathrm{H}$ \\
\hline 13 & & $5 / 478-5-18$ & $\mathrm{~S}$ & $\mathrm{~S}$ & $\mathrm{~T}$ \\
\hline 14 & & 5/478-5-19 & $\mathrm{H}$ & $\mathrm{S}$ & $\mathrm{H}$ \\
\hline 15 & & $5 / 478-5-20$ & $\mathrm{~S}$ & $\mathrm{~S}$ & $\mathrm{~S}$ \\
\hline 16 & & $5 / 478-5-22$ & $\mathrm{~T}$ & $\mathrm{~S}$ & $\mathrm{~T}$ \\
\hline 17 & & $5 / 478-5-23$ & $\mathrm{~S}$ & $\mathrm{~S}$ & $\mathrm{H}$ \\
\hline 18 & & $5 / 478-5-25$ & $\mathrm{~S}$ & $\mathrm{~S}$ & $\mathrm{H}$ \\
\hline 19 & & $5 / 478-5-26$ & $\mathrm{H}$ & $\mathrm{S}$ & $\mathrm{H}$ \\
\hline 20 & & $5 / 478-5-28$ & $\mathrm{~S}$ & $\mathrm{~S}$ & $\mathrm{H}$ \\
\hline 21 & & $5 / 478-5-29$ & $\mathrm{~S}$ & $\mathrm{~S}$ & $\mathrm{H}$ \\
\hline 22 & & $5 / 478-5-30$ & $\overline{\mathrm{H}}$ & $\mathrm{S}$ & $\mathrm{N}$ \\
\hline 23 & & $5 / 478-5-34$ & $\mathrm{H}$ & $\mathrm{S}$ & $\mathrm{H}$ \\
\hline 24 & & $5 / 478-5-35$ & $\mathrm{~S}$ & $\mathrm{~S}$ & $\mathrm{~T}$ \\
\hline 25 & & $5 / 478-5-36$ & $\mathrm{~A}$ & $\mathrm{~S}$ & $\mathrm{~T}$ \\
\hline 26 & & $5 / 478-5-44$ & $\mathrm{H}$ & $\mathrm{S}$ & $\mathrm{H}$ \\
\hline 27 & & $5 / 478-5-46$ & $\mathrm{~N}$ & $\mathrm{~S}$ & $\mathrm{H}$ \\
\hline 28 & & $5 / 478-5-53$ & $\mathrm{H}$ & $\mathrm{S}$ & $\mathrm{H}$ \\
\hline 29 & & $5 / 478-5-54$ & $\mathrm{~N}$ & $\mathrm{~S}$ & $\mathrm{H}$ \\
\hline 30 & & $5 / 478-5-55$ & $\mathrm{H}$ & $\mathrm{S}$ & $\mathrm{H}$ \\
\hline 31 & & $5 / 478-5-56$ & $\mathrm{~S}$ & $\mathrm{~S}$ & $\mathrm{H}$ \\
\hline 32 & & $5 / 478-5-57$ & $\mathrm{~S}$ & $\mathrm{~S}$ & $\mathrm{H}$ \\
\hline 33 & & $5 / 478-5-63$ & $\mathrm{~S}$ & $\mathrm{~S}$ & $\mathrm{~S}$ \\
\hline 34 & & $5 / 478-5-64$ & $\mathrm{~S}$ & $\mathrm{~S}$ & $\mathrm{H}$ \\
\hline 35 & & $5 / 478-5-66$ & $\mathrm{~S}$ & $\mathrm{~S}$ & $\mathrm{~T}$ \\
\hline 36 & & $5 / 478-5-67$ & $\mathrm{H}$ & $\mathrm{S}$ & $\mathrm{T}$ \\
\hline 37 & & $5 / 478-5-69$ & $\mathrm{H}$ & $\mathrm{T}$ & $\mathrm{T}$ \\
\hline 38 & & $5 / 478-5-70$ & $\mathrm{H}$ & $\mathrm{S}$ & $\mathrm{T}$ \\
\hline 39 & & $5 / 478-5-71$ & $\mathrm{H}$ & $\mathrm{S}$ & $\mathrm{H}$ \\
\hline 40 & & $5 / 478-5-72$ & $\mathrm{H}$ & $\mathrm{S}$ & $\mathrm{H}$ \\
\hline 41 & & $5 / 478-5-73$ & $\mathrm{H}$ & $\mathrm{S}$ & $\mathrm{H}$ \\
\hline 42 & & $5 / 478-5-74$ & $\mathrm{~S}$ & $\mathrm{~N}$ & $\mathrm{H}$ \\
\hline 43 & & $5 / 478-5-75$ & $\mathrm{~S}$ & $\mathrm{~S}$ & $\mathrm{H}$ \\
\hline
\end{tabular}

NB: $\mathrm{S}=$ Susceptible, $\mathrm{T}=$ Tolerance, $\mathrm{H}=$ Heterozygous, and $\mathrm{N}=$ Not recognizable $(*)=$ This sequence was used in the banding pattern of salt tolerance of $40 \mathrm{BC}_{1} \mathrm{~F}_{1}$ lines using RM510, RM585 and RM336. 


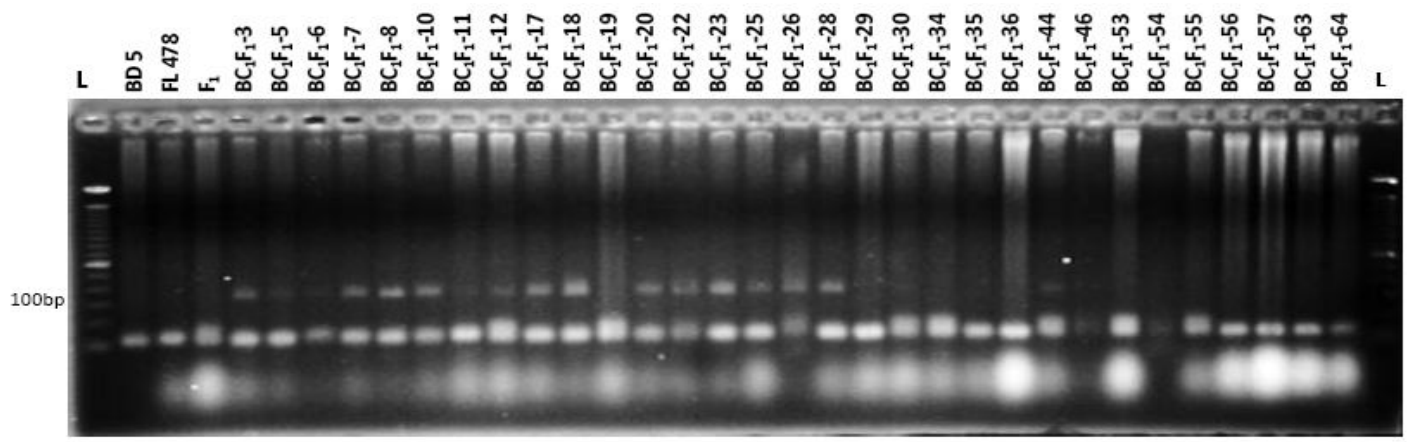

Fig. 1(a). Banding pattern of $\mathrm{BC}_{1} \mathrm{~F}_{1}$ population of Binadhan-5/ FL-478 using SSR marker RM510 from Sl. No. 1 to 34 (Table 2)

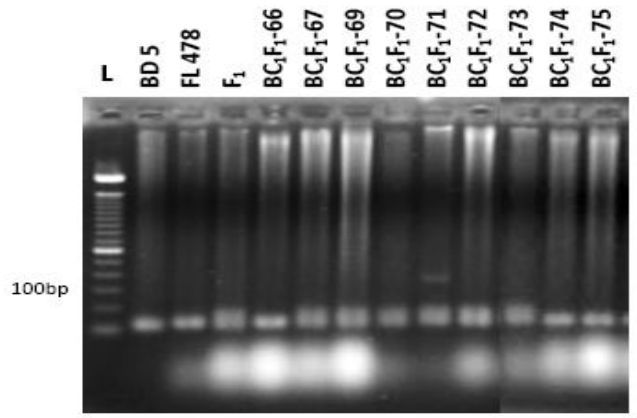

Fig. 1(b). Banding pattern of $\mathrm{BC}_{1} \mathrm{~F}_{1}$ population of Binadhan-5/ FL-478 using SSR marker RM510 from Sl. No. 1 to 3 and 35 to 43 (Table 2 )

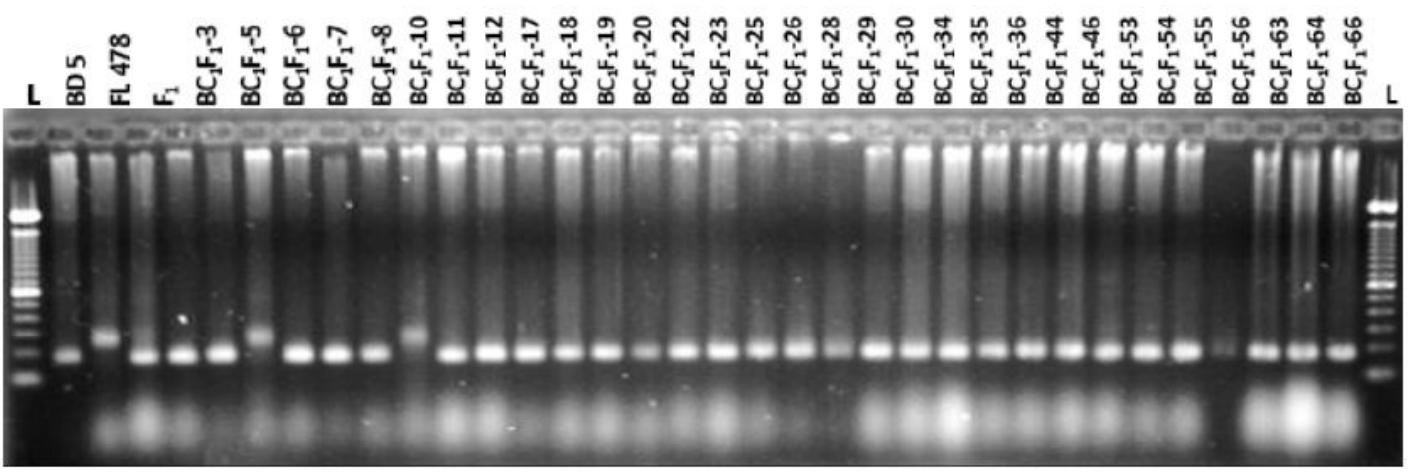

Fig. 2(a). Banding pattern of $\mathrm{BC}_{1} \mathrm{~F}_{1}$ population of Binadhan-5/ FL-478 using SSR marker RM585 from Sl. No. 1 to 34 (Table 2)

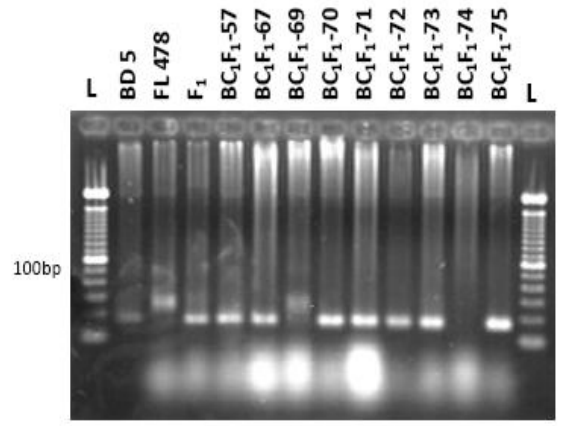

Fig. 2(b). Banding pattern of $\mathrm{BC}_{1} \mathrm{~F}_{1}$ population of Binadhan-5/ FL-478 using SSR marker RM585 from Sl. No. 1 to 3 and 35 to 43 (Table 2) 


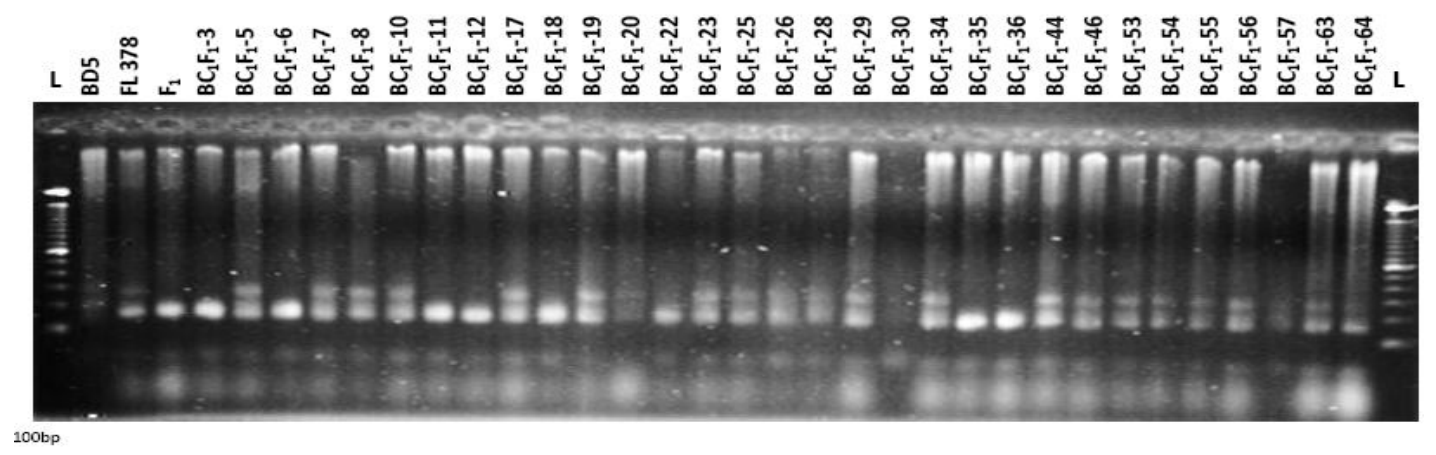

Fig. 3 (a). Banding pattern of $\mathrm{BC}_{1} \mathrm{~F}_{1}$ population of Binadhan-5/ FL-478 using SSR marker RM336 from Sl. No. 1 to 34 (Table 2)

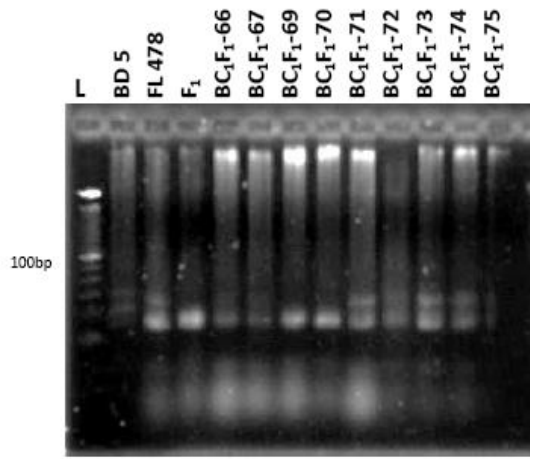

Fig. 3 (b). Banding pattern of $\mathrm{BC}_{1} \mathrm{~F}_{1}$ population of Binadhan-5/ FL-478 using SSR marker RM336 from Sl. No. 1 to 3 and 35 to 43 (Table 2)

\section{Parental poly morphism survey}

Polymorphism of 10 microsatellite primers was examined in the 3 rice samples; two parents, and $\mathrm{F}_{1}$. Of 10 SSR primers, 3 showed marker polymorphisms to the parents. Of the remainder, some showed no amplification and hazy bands; some gave amplified products, but these were monomorphic. These three primers (RM336, RM510, and RM585) showed clear bands among the $40 \mathrm{BC}_{1} \mathrm{~F}_{1}$ rice samples. Out of $85 \mathrm{BC}_{1} \mathrm{~F}_{1}$ rice leaf samples, randomly 40 leaf samples were used for genotyping performance.

\section{Genotypic performance of parents, $F_{1}$ and} $\mathrm{BC}_{\mathbf{1}} \mathrm{F}_{\mathbf{1}}$ against SSR markers

The banding patterns were scored with reference to those of FL-478 and Binadhan-5, since FL-478 is salt tolerant and Binadhan- 5 is salt susceptible. In each marker, allelic bands were scored based on the parental bands and designated as $\mathrm{T}$ for tolerant, $\mathrm{S}$ for susceptible and $\mathrm{H}$ for heterozygous (Table 2).

\section{Overall performance of $B_{1} F_{1}$ rice lines against the RM510, RM585 and RM336}

$\mathrm{BC}_{1} \mathrm{~F}_{1}$ rice lines showed wide variation with three primers; RM510, RM585 and RM336. In respect of primer RM510, a total of 16 lines (2 lines were similar to donor parent type FL-478 and 14 were heterozygous) were identified [Fig. $1(\mathrm{a}, \mathrm{b})$ ] having salt tolerant gene derived from backcrossing between $F_{1}$ (Binadhan-5×FL478) and Binadhan-5.

With respect to the primer RM585, total 4 lines (lines were similar to parent FL-478) were identified [Fig. $2(\mathrm{a}, \mathrm{b})$ ] having salt tolerant gene derived from backcrossing between $F_{1}$ (Binadhan-5×FL478) and Binadhan-5.

With respect to the primer RM336, total 34 lines (29 lines were recurrent parent type Binadhan- 5 and 5 were heterozygous) were identified [Fig. 3 $(\mathrm{a}, \mathrm{b})$ ] having salt tolerant gene derived from backcrossing between $F_{1}$ (Binadhan-5×FL478) and Binadhan-5.

Shaon (2009) conducted a study to identify salt tolerant rice lines of segregating $\mathrm{F}_{2}$ progenies of Mut-1-1×Charnock (DA6) using SSR markers. According to his study, 12 microsatellite (SSR) markers (RM9, RM155, RM336, RM32, RM169, RM80, RM310, RM18, RM594, RM585, RM7075 and OSR17 primers) were used for parental polymorphism survey of Mut-1-1 and Charnock (DA6). Among the tested primers, three SSR primers (RM9, RM336 and RM585) showed polymorphisms between the parents [Mut-1-1 and Charnock (DA6)]. In the present study similar type of result were found for parental 
polymorphism of Binadhan- 5 and FL-478. Among the used primers RM336, RM510 and RM585 showed polymorphisms between the parents. Thus in this study $25 \mathrm{BC}_{1} \mathrm{~F}_{1}$ heterozygous were identified through RM336 having salt tolerant gene derived from backcrossing between $F_{1}$ (Binadhan-5×FL478) and Binadhan-5. With respect to the primer RM585, 4 lines were identified having salt tolerant gene derived from FL-478 (donor parent).

Three primers (RM336, RM510 and RM585) showed polymorphisms in the studied parents, their $\mathrm{F}_{1}$ and their $\mathrm{BC}_{1} \mathrm{~F}_{1}$ population and they showed different banding patterns and discriminate tolerant lines from susceptible with relation to their tolerant (FL-478) and susceptible (Binadhan-5) parents. Those markers were also reported as highly polymorphic in IR29 $\times$ Pokkali for tagging salt tolerant genes (Islam, 2004; Niones, 2004). El-Refaee et al. (2006) also reported that $80 \%$ of the all tested SSR primers showed polymorphic pattern in rice while they studied 272 SSR primers on nine rice genotypes.

The tested markers RM510, RM585, and RM336 could be efficiently used to identify salt tolerant lines in rice and can also be used in markerassisted selection (MAS) for breeding, quantitative trait loci (QTL) mapping and gene pyramiding in rice salinity breeding. The selected salt tolerant rice lines would be further tested in saline areas to observe yield potentiality for developing high yielding salt tolerant varieties.

Further investigation will be needed to the selected lines of $\mathrm{BC}_{1} \mathrm{~F}_{1}$ population i.e., recombination selection and background selection. But due to some constraints like limitation of stipulation of the study, unavailable time table, limitation of our resources and man power, recombinant and background selections were not possible to carry out. After the recombination selection and background selection have been completed, the selected lines of $\mathrm{BC}_{1} \mathrm{~F}_{1}$ population will be further backcrossed for the development of $\mathrm{BC}_{2} \mathrm{~F}_{1}$. After that $\mathrm{BC}_{2} \mathrm{~F}_{1}$ population will be transformed into $\mathrm{BC}_{2} \mathrm{~F}_{2}$ population through self-pollination for increasing the number of the population. And that population will be undertaken for the QTL mapping for salinity tolerance.

The identification of a major gene locus for salt tolerance near a microsatellite marker can be used by plant breeders to select more efficiently to better understand salt tolerance at the reproductive stage. Other microsatellite markers could be used to trace the flow of genes or quantitative trait loci of interest in rice and to make predictions about the outcome of the crossing and selection programs that will help in improving salt tolerant rice varieties.

\section{Conclusions}

Salt tolerant rice lines were identified genotypically (identification with SSR markers) in $\mathrm{BC}_{1} \mathrm{~F}_{1}$ generation. The tested primers RM336, RM510 and RM585 in the $\mathrm{BC}_{1} \mathrm{~F}_{1}$ rice lines could be efficiently used to identify salt tolerant lines and could also be used in marker assisted breeding, quantitative trait loci (QTL) mapping, genetic diversity study and gene pyramiding in rice salinity breeding. Thus, these markers could be efficient for tagging salt tolerant genes, in marker assisted selection (MAS) and quantitative trait loci (QTL) mapping.

\section{References}

El-Refaee, Y.Z., Atallah, M. and Porceddu, E. 2006. Fine QTLs mapping for salinity tolerance in rice. Proceedings of the 50th Italian society of Agricultural Genetics Annual Congress. Ischia, Italy. (ISBN 88900622-7-4).

Gregorio, G.B., Senadhira, D., Mendoza, R.D., Manigbas, R.D., Roxas, N.L. and Guerta, C.Q. 2002. Progress in breeding for salinity and associated abiotic stresses in rice. Field Crops Res. 76: 91-101.

IRRI (International Rice Research Institute). 1997. Rice Almanac. IRRI-WARDA-CIAT, Los Baños, Laguna, Philippines. 181 p.

Islam, M.M. 2004. Mapping salinity tolerance genes in rice (Oryza sativa L.) at reproductive stage. Ph.D. dissertation, University of the Philippines Los Baños College, Laguna, Philippines. pp. 1-149.

Islam. M.M., Mondol, M.N.H., Emon, R.M., Begum, S.N., Bhowmik, S.K. and Hasan, A.K. 2007. Screening of salt tolerant rice genotypes using SSR markers at seedling stage. Bangladesh J. Prog. Sci. Tech. 5 (1): 45-48.

Lin, H.X., Yanagihara, S., Zhuang, J.Y., Senboku, T., Zheng, K.L. and Yashima, S. 1998. Identification of QTL for salt tolerance in rice via molecular markers. Chinese J . Rice Sci. 12 (2): 72-78.

Maclean, J.L., Dawe, D.C., Hardy, B. and Hettel, G.P. 2002. Rice Almanac. Los Baños (Philippines): International Rice Research Institute, Bouake (Cote d'Ivorie): West Africa Rice Development Association, Cali (Colombia): International Center for Tropical Agriculture, Rome (Italy): Food and Agriculture Organization. $253 \mathrm{p}$.

McCouch, S.R., Chen, X., Panaud, O., Temnykh, S., Xu, Y., Chao, Y.G., Huang, N., Ishii, T. and Blair, M. 1997. Microsatellite marker development, mapping and applications in rice genetics and breeding. Plant Mol. Biol. 35: 89-99. 
Niones, J.M. 2004. Fine mapping of the salinity tolerance gene on chromosome 1 of rice (Oryza sativa L.) using near-isogenic lines. MSc. Dissertation, University of the Philippines Los Baños College, Laguna, Philippines. pp. 76-78.

Panaud, O., Chen, X. and McCouch, S.R. 1995. Frequency of microsatellite sequences in rice (Oryza sativa L.). Genome. 36: 170-176.
Shaon, S.A. 2009. Identification of salt tolerant rice lines of segregating $F_{2}$ progenies of Mut-1-1× Charnock (DA 6) using SSR markers. MS Thesis, Department of Biotechjnology, Bangladesh Agricultural University, Mymensingh. pp. 35-56.

Siddika, A., Islam, M.M., Begum, S.N., Bhowmik, S.K. and Nasiruddin, K.M. 2007. Screening of Rice Germplasms under salt stress and Identification of Salt Tolerant Genes via SSR Markers. Bangladesh J. Environ. Sci. 13 (1): 65-70. 